\title{
Activists communication dynamics for mobilization of minority politics in europe
}

\author{
Teguh Luhuringbudi ${ }^{\mathrm{a}, 1, *}$ \\ Muhammad Din Syamsuddin ${ }^{\mathrm{b}, 2}$ \\ Sudarnoto Abdul Hakim ${ }^{\mathrm{c}, 3}$

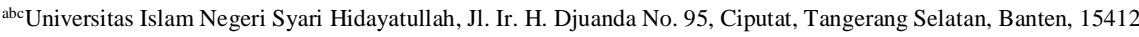 \\ ${ }^{1}$ sampaiteguh@gmail.com* \\ 2 msirajuddinsyamsuddin@gmail.com \\ ${ }^{3}$ Sudarnoto.hakim@gmail.com \\ * corresponding author
}

ARTICLE INFO

\section{Article history}

Received 2019-09-19

Revised 2019-09-25

Accepted 2019-09-29

Keywords

Activists

Communication

Mobilization

Politic

Europe

\section{ABSTRACT (10PT)}

This paper aims to proves that the diversity of minority attributes in a person becomes the main capital in winning direct political contestation through election; or indirectly through unilateral appointment. It is characterized by five Muslim politicians who are able to sit in political office with the capital of political biography, social biography, and or intellectual biography. This research uses three methods in the form of political biography, social biography, and intellectual biography. Political biography consists of opinions or thoughts expressed by David Hanlon (2015); and opinions or thoughts of Anastasia Astapova (2016). The social biography used in this study refers to the thought of Smiljka Tomanović (2012). The intellectual biography used in this study is based on the thoughts of Damián Omar Martínez (2013) and the thinking of Thomas Hylland Eriksen (2015). The study was limited to five Muslim politicians comprising Jilani Chowdhury (Mayor of London, 2012), Ahmed Aboutaleb (Mayor of Rotterdam, 2008), Muhammad Salique (Mayor of Tower Hamlets, London Raya, 20082009), Erion Veliaj (Mayor of Tirana, 2015 ), Sadiq Aman Khan (Mayor of London, 2016), and Hadia Tajik (Norwegian Minister of Culture, 2012). This study is limited to the study of European Muslim Politicians in the perspective of a major theme. This study is also limited during the study that took place in Europe in 2012 until 2016.

This is an open access article under the CC-BY-SA license.

\section{Introduction}

Democracy and religious freedom are the basis for ensuring levels of social political health. Democracy serves as an incentive for the presence of matriculative values in conveying thoughts by anyone. Freedom of religion serves to give choices for everyone to enrich their respective minds by supplementing the value of religiosity. Political health is at stake with two conflicting conditions [1]. 
The first condition requires the portion of religion in the guarantee of organizing and the succession of political parties. Evans and Kelley stated that voting in some advanced societies is closely related to religious issues rather than socioeconomic issues. The second condition places the politics of common sense proportionally in ensuring transparency, objectivity, and political quality [2]. Hout, Fischer, Hayes, and McAllister support the second condition by arguing that atheists or apostates tend not to be politically conservative and tend to oppose religion in politics [3]. This indicates that rationality as a hidden message is an offer of quality assurance in the implementation of political activities. Both of these conditions lead to a rule that freedom of religion in a variety of social political activities is a manifestation of realistic democracy.

The religious leaders' role is one of the ideals that need to be considered in the political sphere. Lugo argues that religious leaders must have a major influence in politics [4]. The idea is to gain approval because religious issues are the primary needs of society generally. The view of the role of religion in politics has a probability that influences attitudes to lean toward Islamic political parties [5]. The presence of the ideas of Islamic political parties cannot be translated as they are. Translation of Islamic political parties can be presented differently such as individual dimensions such as Muslim politicians or the nuances of Islamic policy.

Morality is an important element of concern in political discourse, religious and society. Lugo stated that the urgency in trusting God was the basis of consideration. for being a moral person [6]. A moral person is a human being chosen within the scope of society who is always faced with the right and obligation to translate social justice. Miller considers that the elements of social justice are innovative concepts of organic society [7]. Society is considered an organism [8]. The idealism of these organisms is the advancement of elements of social justice that demand cooperation from all sides and aim at specifying arrangements that will allow everyone to contribute in totality to being social well-being [9]. Subject modalities, namely morality and the ideal vision of the subject, namely social justice are often confronted with religious dogma, value dogma, or cultural dogma that is preserved in a society collectively and in a state administratively [10]. The morality of someone to appear on the service or political stage is required to adjust to the elements of dogma such as structure, content, and belief systems that apply in that locality [11]. Interconnection of morality and dogma of a society which tends to involve religious sentiments in politics will affect the performance and realization of social justice.

\section{Theorical Framework}

\subsection{Civil and Muslim Society}

The discourse of the definition of vertical mobilization is an initial consideration in the theoretical debate of this research. DiPrete laid down the definition of vertical mobilization by contextualizing and describing the conditions of workers. DiPrete defines vertical mobilization with overall structural movement through hierarchy with bureaucratic personnel procedures [12]. This comprehensive stryctural movement involves civil society as an interactive fact of humanity. Vertical mobilization can be understood as the movement of individuals or groups into certain positions involving changes in class, status, and strength in a society.

Civil and Muslim societies are debates that give birth to an alternative movement in responding to inconsistencies. Religious demographic variables are perceived as a mismatch if Islam is juxtaposed with civil society [13]. The fundamentalist argument reinforces this by stating that although Muslims are not an inferior ethnicity-community, Islamic civilization is imperfect and decadent. It was denied by the normativity of the vision of Islam, Rahmatan lil 'Álamin. The normativity of the Islamic vision is subsidized by civil rights normativity, namely matriculation of justice. It is evidenced by reports of violations of Muslim civil rights in the context of securitization [14]. It dialectic leads to political practice based on "normality."[15] Normality that appears in a limited manner has indicated the existence of a rationality by excluding religious sentiments and hegemonic prides-powers. The impact of normality and rationalism is the emergence of awareness to conduct a "collective-collegial movement" in Europe. 


\subsection{Cases of Politicians}

The achievement of strategic positions by Muslim politicians in a political context (whether in the cabinet or opposition) presents a minority phenomenon vertically ("vertical mobilization"). The occupation began with the limitation of four countries which were set aside in this study in the form of England (United Kingdom) with the capitals of London, Norway, Netherlands with the capital Amsterdam, and Albania (Albanian Republic, Republika e Shqipërisë) with the capital Tirana. The European continent consisting of 48 countries presents the uniqueness of the presence of politicians in the four countries mentioned above. Evidence of the position of Muslim politicians can be seen from Jilani Chowdhury who became mayor of London.

in 2012, Ahmed Aboutaleb as mayor of Rotterdam 2008 in the Netherlands, Muhammad Abdullah Salique as mayor of Tower Hamlets in Greater London in 2008-2009, Erion Veliaj as mayor of Tirana in Albania 2015, Sadiq Aman Khan as mayor of London in 2016, and Hadia Tajik as Minister of Culture in Norway. This achievement can be seen in the chart as follows:

Table 1.

\begin{tabular}{|c|c|c|c|c|}
\hline Politicians & $\begin{array}{l}\text { Position \& } \\
\text { Country }\end{array}$ & Year & $\begin{array}{c}\text { Total } \\
\text { Population }\end{array}$ & $\begin{array}{c}\text { Party \& Voice } \\
\text { of Victory }\end{array}$ \\
\hline $\begin{array}{r}\text { Jilani } \\
\text { Chowdhury }\end{array}$ & Mayor of London & 2012 & & Labour Party \\
\hline Ahmed & Mayor of & October & & Labour \\
\hline Aboutaleb & $\begin{array}{l}\text { Rotterdam in the } \\
\text { Netherlands }\end{array}$ & 2008 & & Party[16] \\
\hline $\begin{array}{r}\text { Muhammad } \\
\text { Abdullah } \\
\text { Salique }\end{array}$ & $\begin{array}{l}\text { Mayor of Tower } \\
\text { Hamlets in } \\
\text { Greater London }\end{array}$ & $\begin{array}{l}2008- \\
2009\end{array}$ & & Labour \\
\hline Erion Veliaj & $\begin{array}{l}\text { Mayor of Tirana } \\
\text { in Albania }\end{array}$ & 2015 & & \\
\hline $\begin{array}{r}\text { Sadiq Aman } \\
\text { Khan }\end{array}$ & $\begin{array}{l}\text { Mayor of London } \\
2016\end{array}$ & 2016 & 5.74 Million & Labour \\
\hline Hadia Tajik & $\begin{array}{l}\text { Minister of } \\
\text { Culture in } \\
\text { Norway }\end{array}$ & $\begin{array}{l}\text { Septemb } \\
\text { er 21, } \\
2012\end{array}$ & & Labour \\
\hline
\end{tabular}

\section{Method}

This type of research is limited to several categories. The first category as the data screening category used in this study is the library research. The second category as data processing in this study is qualitative research. The understanding of vertical mobilization of Muslim politicians uses three perspectives in the form of social biographical perspectives, intellectual biographical perspectives, and political biographical perspectives.

David Hanlon details tracking political biography in five steps. Firstly, the responsibility to ensure the sovereignty of autonomous government. Secondly, network development in ensuring traditional authority. Thirdly, involvement with symbolic organizations. Such involvement can also be seen from persistence and persuasive power in ensuring an independent government. Fourthly, the navigator's metaphor in mapping political careers. This fourth element can be seen from the personality of someone who is quiet, humble, and inconspicuous. Fifthly, passion for congress or social struggles. The fifth phenomenon inherent in politicians can be seen from individuals who try to oppose executive power or financial conditions that experience negative sentiment [17].

Anastasia Astapova opposed the scheme of political biographical indicators expressed by Hanlon by offering different patterns. Astapova provides three indicators in tracing one's political biography. The first indicator is the absence of relationships or incoherence. Dichotomy or binary models are a dialectical process that aborts each other. A figure, politician, or leader tends to reject establishment or a general understanding of something. A person who is involved in a political biography 
discourse will be seen from the aspect of political identity, ethnic, and personality integrity. Opposition people who regard the personality of a particular individual as a dictator will be faced with other personalities such as perseverance and simplicity.

The second indicator is contestation. Mental health, literacy hegemony, and rumor management from a politician or leader are important aspects in seeing the standards of feasibility in the view of the voting society. Mental health which is a necessity of society is the structure of personality and public ethics. The personality structure in question consists of id (desire, ambition, ideals), ego (reality-oriented), and super ego (moral elegance). The public ethics is an effort made by politicians or individuals in presenting bridges, namely a bridge between modalities, actions, and goals. The modality is the realization that politicians have done in presenting facilities and systems for the society that can respond to the needs of the relevant society. Framing editors-redactions in print, electronic, and online media is intended to strengthen positive and negative sentiments in certain figures before the election (democratic party). This is a literacy effort in caring for personal existence on the prospective stock exchange at a democratic party. Another effort taken as a representation of literary hegemony is the distribution of the biographies of politicians before the executive and legislative elections. Rumors about someone tend to be aggressive and destructive in order to minimize rivals or political opponents. The mechanism of rumors also tends to oppose official truths and ask for institutional authority [18].

The third indicator is heroism. This indicator can be appreciated from ethnic heroes and the validity of heroes. The ethnicities are birth, wife and child narratives that have an impact on political power and masculine sexuality. Someone who is identified with his father biologically will get a sign of ownership and increase the legitimacy of certain leaders. It is validity in stimulating opinions about the value of heroism in the minds of the people-society. The positive image of a leader or politician will make people proud to share ethnicity, culture, religion or race with these politicians [19]. The validity of heroism in a person is influenced by ethnic stereotypes in the country, religion, routine charismatic authority, and other custom labels or schemes. The construction of an official picture of a particular politician leads to a general picture that resonates with people with certain primordialities [20].

Table 2.

Model

\begin{tabular}{|c|c|c|c|}
\hline \multirow[t]{2}{*}{ David Hanlon } & \multirow{2}{*}{$\begin{array}{r}\text { Anastasia } \\
\text { Astapova }\end{array}$} & \multicolumn{2}{|c|}{ Analysis of Research Data } \\
\hline & & $\begin{array}{c}\text { Open } \\
\text { Personality }\end{array}$ & $\begin{array}{c}\text { Closed } \\
\text { Personality } \\
\text { (Navigation) }\end{array}$ \\
\hline Sense of Havin & Inherent & $\begin{array}{l}\text { Feelings of } \\
\text { Ownership }\end{array}$ & $\begin{array}{l}\text { Feelings of } \\
\text { Ownership }\end{array}$ \\
\hline Network & contestation & Network & Network \\
\hline $\begin{array}{r}\text { Symbolic } \\
\text { Organization }\end{array}$ & Heroism & Contestation & Inherent \\
\hline $\begin{array}{r}\text { Metaphorical } \\
\text { Navigator }\end{array}$ & & $\begin{array}{l}\text { Symbolic } \\
\text { Organization }\end{array}$ & $\begin{array}{l}\text { Metaphorical } \\
\text { Navigator }\end{array}$ \\
\hline $\begin{array}{r}\text { Surge in Social } \\
\text { Struggle }\end{array}$ & & $\begin{array}{l}\text { Surge in Social } \\
\text { Struggle }\end{array}$ & \\
\hline & & Heroism & \\
\hline
\end{tabular}

A person's social biography can be seen from social interactions and agencies. The four indicators in seeing the formation of social biographies are social contexts including structural features, available resources, agents, and personal identities [21].

The first indicator is supported by the existence of the capital city as a source that needs to be considered in influencing the social context which is then able to influence the social biography of a figure or politician. 
The second indicator is the structure's idiosyncrasies (structural features). The debate arose regarding the urgency of this structural factor. Beck and Beck-Gernsheim argue that structural factors are less significant determinants in the formation of modern needs that are too late for individuals to face and complete their lives [22]. Other experts consider that the structure of socioeconomic status related to the specificity of class, gender, ethnicity, family background, age, environment, and so on are important factors in the biography of the youth [23][24].

The third indicator is resources. That resource is the maturation of a person when entering adulthood. Their maturity value is a representation of their own resources. This maturation formation is based on their own experience stimulated by the structure, both the aspect of resources and habitus. The existence of resources, namely maturity of a person occurs through two processes, namely the process of relational biography and individualized biographies. The first process emphasizes the domestic domain of responsibility and attention to others. This first process compares with the acceleration of the transition to adulthood that occurs in someone with a class background and investment in workers or professionals (not from education). The second process emphasizes education and profession (career) which are characterized by levels of maturity and autonomy [25]. The second process with the tendency of investment in the field of education is a field of competence that affects individual biographies and has the potential to be seen as a middle class. The second process with the tendency to invest in work will affect relations and domestic domains.

The fourth indicator is the agent. Agents are defined as the ability of individuals who are knowledgeable and active to act intentionally, but do not have to consciously, recognize all the potential consequences of the actions taken [26]. Discussion of agents is influenced by habitus. Habitus (body stature and condition) affects the formation of social biographies with two things. First, habitus can direct the empowerment of family resources as the capital city. Second, habitus on certain agents is useful in applying certain behaviors [27].

Table 3.

\begin{tabular}{|c|c|}
\hline \multirow{5}{*}{ 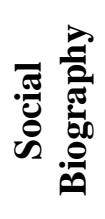 } & social context \\
\hline & structural features \\
\hline & available resources \\
\hline & Agent \\
\hline & Personal Identity \\
\hline
\end{tabular}

A person's intellectual biography in Eriksen's view is based on four things including coincidence, naturalist disposition, national character, and assertive statements about agents [28]. The coincidental element referred to by Eriksen is a prediction that is addressed in a real way and is aimed at someone in a condition or something that is in the future. The fact that there is in the future is not infrequently sided or proven by beginning with the prediction or attitude chosen by someone. Naturalist disposition is a scientific personality. Something that can be used as a measure of one's scientific personality can be seen from habits such as "watching and wondering," hiring competent research assistants, and adequate reading skills. National character is an attitude and action that accommodates the interests of territorial state identity and social identity. A firm statement towards an agent is an effort to simplify the process of identifying someone to another person so that it generates novelty news to facilitate the diaspora of various social strata.

Damián Omar Martínez describes the unity of intellectual biography in examining someone with several elements. The intended element is motivation for certain disciplines, synergy between experience and academics, involvement of public intellectuals, scientific ideas that are free of value, and intellectual influence. These five elements are tools to measure and assess the level of intellectual biography in a person.

The five elements of the formation of an intellectual biography are described as follows. First, the motivation to know something can influence the choice of someone's interest, then it can be 
responded positively by learning it, researching it, applying it, and reflecting it [29]. Second, the duality between experience and academics is intended to present information and a climate of knowledge that is up to date. The indicator that can be used in this second element is tracing field research and surveys.

Third, the intended public intellectual engagement is a contribution to public debate through the creation of public profiles, academic consolidation, and the media on developing issues [30]. Fourth, value-free ideas and opinions are an effort to present a conceptual enlightenment and proof without involving interference in values, politics, and governance. Value-free ideas and opinions are also based on one's expertise in certain disciplines or issues which ultimately becomes a consideration in measuring the level of career professionalism of an academic [31]. Fifth, intellectual influence is the perceived impact of someone who is examined philosophically or as a role model of speech, writing or research, actions, and attitudes [32].

Table 4.

\begin{tabular}{|c|c|c|}
\hline Methode & Varian Methode & Type \\
\hline \multirow{8}{*}{ 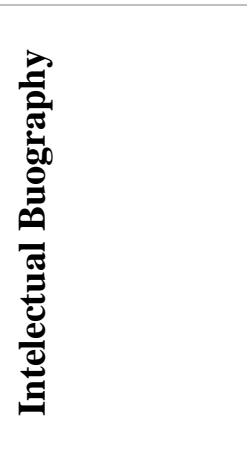 } & \multirow{4}{*}{ 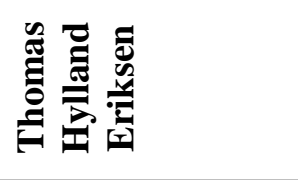 } & Incidentally \\
\hline & & Naturalist disposition \\
\hline & & National character \\
\hline & & Assertive Declaration on Agents \\
\hline & \multirow{4}{*}{ 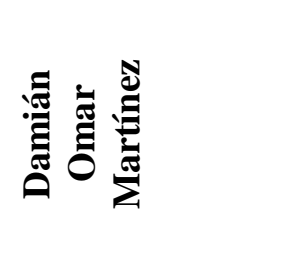 } & $\begin{array}{lll}\text { Motivation } & \text { against } & \text { certain } \\
\text { disciplines } & & \end{array}$ \\
\hline & & $\begin{array}{l}\text { Synergy between experience and } \\
\text { academic }\end{array}$ \\
\hline & & Public intellectual involvement \\
\hline & & A value-free scientific idea \\
\hline
\end{tabular}

\section{Results and Discussion}

\subsection{Jilani Chowdhury}

Networking is the first aspect in seeing Jilani Chowdhury's political career. The most decisive political career before Chowdhury took office as a public official in a political context was his involvement as a board member (in Barnsbury) [33] in 2007/2008 and 2008/2009 in Islington. This experience shaped his instincts and political movements that departed from the Labor Party. He who has lived in Barnsbury since 2006 is classified as someone who is able to adapt quickly.

Jilani Chowdhury was present as the representation of the first Asian figure to become the mayor of Islington (London) in 2012 [33], an area that had a population of 206,100 people in 2011. The surge in the congress or social struggle was an esoteric appearance of the Chowdhury figure. The specificity of the political nuances can be seen from its position as a minority figure who is able to resist the domination of indigenous people. The minimal population of Islington is indeed seen as an easiness to distribute thoughts to the mayor election contestants, but his short stay after moving from Barnsbury is a surge and persistent efforts in presenting public services for the development of community political welfare and local social struggle.

His student status was utilized for the expansion of the humanitarian network with the position he once held as Secretary General of the Bangladesh Civil Service Association which functioned to provide for the rights of trade unions and employees. The social character that emerges from the figure of Chowdhury is an agent. The status of students as agents of change and social control is not superfluously pinned on Chowdhury's social personality which seeks a conducive interpenetration climate of internal and external factors so that the symptoms and culture of neglect of workers 'and employees' rights become the main target of resistance [34]. Chowdhury's social struggle as a student dubbed the "agent of social control" actually targets Sophie Hennekem's and Dawn Bennett's research findings relating to improvements in quality of life that can be detailed by minimizing improvements in non-standard occupational forms and persistence of precarious work throughout career life; increased initial education and training with specific reference to business skills; providing access to needs and promoting life-long professional learning challenges; and creating a 
climate of awareness of access to benefits and protection [35]. The various aims of the struggle for the rights of workers and employees lead to new networks originating from each of these goals so that social maturity grows in the form of network expansion. The acquisition of a new social network that takes into account Chowdhury's position as a person who has a firm and disciplined personality makes him not only seen as a human resource that deserves to be taken into account in the context of workers 'and employees' rights, but eases the role of his vertical mobilization for creating a climate of equality and eligibility for workers and employees.

Jilani Chowdhury who once worked as a volunteer in the housing sector for parents revealed a social character that is thick with the process of relational biography. The acceleration of the transition to adulthood marked by his decision to work in the public service sector cannot be seen as a symptom of social investment, but also as a distribution of happiness that appears to be inherent in Chowdhury's instincts. This relational biographical process of his work requires Chowdhury to be present in the public justice space.

Jilani who started her social relations by moving to Islington in 1992 by raising her three children seemed to have a strong personality in terms of structural features. Chowdhury's social status structure related to the distinctiveness of the educated class made him try to gain more promising new experiences and thoughts as social investments. The adaptation he experienced in England not only required him to be active in horizontal mobilization and vertical mobilization, but sharpened his social instinct to see and take advantage of opportunities. This kind of foresight is not only the capital of the uniqueness of its personality structure, but is an important ingredient for mobilizing vertically owned resources.

Health problems are one of Jilani Chowdhury's social concentrations in Islington as a form of responsibility to ensure autonomous government. Islington is known as an area that has indications of cardiovascular disease (CVD), cancer and chronic obstructive respiratory disease (COPD) is a picture of inequality in life expectancy between Islington (specifically) with the UK (generally), although Bangladesh ethnic groups show ownership of a prevalence that is very high than the long-term condition diagnosed. His attention to health problems has invested his social capital as a political step for vertical mobilization in election contestation.

Jilani who served as the first Bangladeshi mayor in Islington often spent his free time with family, promoting multicultural activities in London, and watching football and cricket. Jilani Chowdhury is a student who is critical of government policy and always grants his energy and intellectual potential for the benefit of many people. Chowdhury was once involved in a national political turmoil that put an attitude of resistance against his student status against military rule in Bangladesh

\subsection{Ahmed Aboutaleb}

Ahmed Aboutaleb's political career network cannot be separated from the symbolic organization that drove him. Aboutaleb is a cadre of the Labor Party. The political position he won was initiated when the Labor Party as a symbolic organization nominated itself as a member of the Alderman cabinet in Amsterdam in 2004 to 2007 and a fourth member of the Balkenende cabinet in 2007 to 2008 from the Labor Party (PvdA). His political career has improved with the trust that Aboutaleb has to account for when serving as Secretary of State for Affairs and Employment. The existence and political achievements of Aboutaleb brought him back and succeeded in becoming mayor of Rotterdam, the Netherlands in 2009 . These symbolic networks and organizations that colored the life experience of Aboutaleb formed a personality building known by Rotterdam residents as a figure that upholds religious freedom, freedom of expression, and non-principles -discrimination. Aboutaleb's personality building gives effect to the meaning of the people of Rotterdam that the city of Rotterdam is not a city that marginalizes people based on minor symbolic networks and organizations, but a city that provides satisfaction and prosperity based on talent, education, and ambition in order to ensure practical use values and fairness- massive humanity.

Ahmed Aboutaleb's intellectual narrative underwent a drastic change which was influenced by the element of "coincidence" in the perspective of intellectual biography. His intellectual journey began with being in his childhood and adolescence under the care of his father as a Sunni Berber Imam (rif) in a small village in Nador, Rif region. Religious education is a priority emphasized by Aboutaleb's father when taking care of him. A major change occurred in the mindset and 
intellectuality of Aboutaleb (at the age of 15) when he decided to accept the invitation of his mother and siblings to migrate to the Netherlands in 1976. This condition forced him to adapt from a rotebased intellectual pattern or memory to thought critical and systematic. This was done in the family reunion room after Aboutaleb's father first arrived in the Netherlands.

The reunion that demanded that the family of Aboutaleb live in The Hague was the beginning of his academic journey which was critical and systematic. This element of "coincidence" brings Aboutaleb to study at LTS (Lower Vocational Technical School), MTS (Technical Secondary School), and HTS (Technical College) and successfully graduated at the B.A. in the field of telecommunications in 1987. Forging a systematic and structured intellectual tradition in the three educational institutions that Aboutaleb participated in did not necessarily reduce the artistic power that exists in him and was proven by his passion and status as a true lover of poetry.

Aboutaleb's intellectual journey in adulthood was also influenced by the element of "coincidence." This began in his first career in journalism in the mid-1980s. The engineering that Aboutaleb learned was gradually reduced and led to the field of social science which was gradually showing maximum results by being marked from his position as moderator on RVU television. Certain conditions caused Aboutaleb to synergize with his lecture material when he was given the responsibility to become a mechanical and network technician in programming on the Amsterdam Stad radio and several other radios in the Netherlands. The additional capabilities he possessed from the world of Communication and Media also complemented the intellectual capital Aboutaleb with the task he had to carry as a reporter for Radio Veronica, Radio NOS, and RTL4 news.

The coincidence in the matter of a career based on knowledge enrichment was again experienced by Aboutaleb. The boredom Aboutaleb felt in his media and communication career made him decide to turn around in the world of work related to the technical discipline he had learned in the previous academic period. This sudden decision was addressed to the involvement of Aboutaleb as a worker in the Ministry of Health and Social Welfare Culture in 1991, the Social Economic Council (SPS), and the Statistics Center (BPS). New careers that are different from the Media and Communication previously delivered Aboutaleb as practitioners of a definite scientific family and a social scientific group. The combination of these two scientific variants was further tested when Aboutaleb became director of the FORUM (Institute for Multicultural Development) in 1998 and he was elected director of the Social Economic and Cultural Development (MEC) sector of the Amsterdam municipality in 2002. Two experiences as a director he felt were the basis considerations that emphasize rich intellectual capital and nuances of public intellectual because it allows learning experiences to adapt to career experiences.

\subsection{Muhammad Abdullah Salique}

Muhammad Abdullah Salique who was elected to the 2006 Bethnal Green North City Council has a strong political capital with a level of contestation experience. His position as the City Council is a proof of the standard of worthiness of the people's views regardless of the primordial (Islamic) background of identity, let alone the ideological war (the war of ideology) which has a lasting impact [10]. Salique's election as a City Council that handles various issues of education, religion, social life, health, politics, and economy [36] is a portrait of the vertical mobilization of Muslim politicians in political contestation.

Muhammad Abdullah Salique or commonly known as Muhammad Abdus Salique who served as Mayor of Tower Hamlets, Greater London (2008-2009) was the fifth Mayor of Tower Hamlets who was blooded in Bangladesh. Salique who was born on August 1951 in Sylhet, East Bengal (now Bangladesh) is a politician who has the responsibility to ensure the sovereignty of an autonomous government. This responsibility can be proven in four ways. Firstly, Salique he has given British citizen certificates to people at the Citizenship Ceremony at the Banqueting House, in Whitehall. The event "national citizenship" is not only seen as an important identity of a country [37] at the Citizenship Ceremony in Whitehall which can be seen as an effort to increase population, but also as an effort to facilitate the implementation of the basic objectives of an organization, government, and society [38]. The ceremony, which involved forty people from various countries to pledge allegiance to the Queen, was a horizontal mobilization targeting psychological, diplomatic, political and social aspects. 
Secondly, Muhammad Abdullah Salique who visited the Billingsgate Market in the fish market managed by City Corporation together with the Mayor of London (Lord Mayor of London) David Lewis is an image of local responsibility. Salique's responsibility in paying attention to public spheres and services is a communication strategy that is implemented to provide a maximum range of services and provide stimulus memorabilia. The wholesale fish market in London, which has existed since 1699 [39], was the object of proper political communication for Salique to avoid the tendency to abstraction of social realities into economic theory and political theory seksual so that vertical mobilization between public officials and the public became productive friendship interactions to produce various types of conversation specific justice and a comfortable work environment for traders in completing the tasks of their commercial profession [36]. The moral responsibility of communication to find out the social, economic, and environmental conditions of a community in an area is Salique's political step that can reach many constituents to be faithful to his side in the political agenda.

Thirdly, Salique who chose the Child Concern Consortium as his Charity of the Year, and invited the charity to the Christmas Charity Ball in East Wintergarden in Canary Wharf was a step in social and political communication. Salique's social care for children communicated through a systematic agenda is a transformational practice of Islamic polity because it accommodates the commands of the Koran (orphan compensation), carries out political constitutional duties, chooses crowded places as "social leverage", and publicity publicity. Religious, political, and social responsibilities located in crowded areas (East Wintergarden in Canary Wharf) are efforts to maintain political stability consisting of geography, ethnic and linguistic identity, differences in social status, economic position, and religious ideology in certain areas so as not to experience framing intervention from outside [36].

Fourthly, the presence of Salique at the Award Ceremony of the Brick Lane Youth Development Association (BLYDA) and Elite Youth at Mulberry School for Girls on May 28, 2008 is a personal representation of social responsibility so that local government autonomy in the fields of education, welfare, health, and economy can be subsidized by community participation.

Salique's social narrative that began with his move from Bangladesh to Tower Hamlets, London in his childhood was a portrait of the visceral structural features of his social biography. The distinctiveness of the proletarian class, African-Asian ethnicity, immigrant family background, and young age Salique are important factors of maturity in the development of youth biographies. The freedom of Bangladesh's facilities and infrastructure compared to Britain is the result of Salique's contemplation of making risky decisions that radiate the nuances of the struggle to risk his future and quality of life so that the situation affects his personality and determination. Salique studied at Spitalfields elementary school. Spitalfields which is a linguistic minority education area that emphasizes the roots of religious ideology so that Salique has the structural feature peculiarities through social views as evidenced by his experience in adopting social, linguistic rules, and cognitive classrooms [40].

Young Salique who is an accomplished and active figure as a social worker and community activist is known for his open personality as a form of social content containing high levels of resources. Salique's resources are evidenced by his involvement in teaching young people at Tower Hamlets College. Salique's youthful activities as a social worker and community activist who necessitated the social division of his vertical mobilization can be seen as a political aspect of Islamic history wherever related to the way Muslims organize the life of the state and government [36]. Salique's social responsibility to teach children at Tower Hamlets College is not only aimed at ensuring local educational and social sovereignty in the context of future regeneration, but also targeting the continuation of a more productive exchange of social discourse.

\subsection{Erion Veliaj}

Erion Veliaj's symbolic network and organization are marked from aiming at the nuances of heroism. Some senior figures of the largest government parties have awarded property legalization certificates at campaign events and some AEA (Alliance for European Albania) candidates such as Veliaj are misusing state events and resources for campaign purposes. Government parties as a symbolic organization that cannot distinguish the separation between state and party and violate paragraph 5.4 of the OSCE Copenhagen document in 1990 is an effort to maximize the power network with the people with a heroic nuance. Indisciplinary activities that utilize state resources for 
the benefit of the sectarian-subjective-party are the rejection of the distance between the government-power network with the people's network, so that this negative nuanced activity still has its own level of heroism.

The surge in the struggle was shown by Veliaj in several actions to gain public trust. The inauguration of the park "Rightous among Nations" involving Veliaj and foreign minister Ditmir Bushati at the Promoting Human Rights event through the Lens of Holocaust Education and Remembrance is one of the efforts he made to introduce his personal bargaining power in the society.

MJAFT organization is a symbolic organization that cannot be separated from Veliaj. This organization was founded by Veliaj in 2003. Veliaj's talent in speeches was well honed because this organization served to raise awareness and inspire a spirit of demonstration related to three important issues namely social, educational, and political[41] in Albania. His resistance in the demonstration along with members and sympathizers of MJAFT received an award from the United Nations given by Kofi Annan because his method was considered efficient in creating change. The surge in Veliaj and MJAFT's speeches made him more known until November 2007 and was elected as an Albanian Parliamentary candidate in 2009 [41].

This symbolic organization led Veliaj to a political-related communication network. Veliaj joined the symbolic organization of the European continent (EU) in the framework of European Stability and promoted the existence of the EU to Eastern and Central Europe from 2007 to 2009. This regional political experience led to the public's need to make Veliaj a member of the Albanian Socialist Party Steering Committee in 2011. This is what makes the lines of communication and political networks spread on international and national scale so that its presence in the Socialist Party immediately occupies the position of Youth and Emigration Secretary. This political communication network that began to be built up was translated by Veliaj by forming a symbolic organization, namely the opening of a branch of the Socialist Party in Greece and Italy.

The social narrative in Erion Veliaj was formed from his position as an agent so as to reveal a distinctive personal identity. Veliaj was involved as the head of the organization (G99) which focused on efforts to "democratize" democracy, namely involving citizens to get closer to government in every aspects [41]. This position is a consequence of his social progress at an international level as evidenced by his career. Career evidence he has taken is involvement in international organizations such as UN institutions or organizations, the OSCE, the Council of Europe, and the Open Society Institute [41]. Veliaj began his leadership position in his job as the leader of MJAFT (a movement that encouraged change in Albanian political development) from 2003 to 2007. These experiences strengthened his position as an agent bound to an agency so that the professional character indirectly emerged in him and ultimately the general public increasingly knew him, especially when he was a member of the board of directors of the Balkan Children and Youth Foundation as well as several regional philanthropy and think tanks. Academic foundations in politics that are parallel to social activities and careers require the international community to make him speaker in Albania and the Balkans in the European Parliament, the US Congress, and also at regional conferences and universities-campuses. This is what makes his personal identity known to someone who masters academics in politics, flexible social relations, and the practice of political values that are oriented to the basics of humanity.

Erion Veliaj has a track record of disciplinary motivation that is proportionate to his experience and academics. Veliaj underwent his undergraduate studies in Political Science at Grand Valley State University, Michigan, USA and continued the University of Sussex, England with an M.A. in the field of European politics. This international-based intellectual footprint is followed by a career pursued by Veliaj in the Balkans, Central and South American Caucasus; and East Africa.

Synergy between experience and academics can be found in many cases of Veliaj's career. One interesting case was when Veliaj was appointed by the Socialist Party as a MP candidate for the Gjirokastra district. The task he took during the campaign was organizing the voting process for Albanian immigrants. This resulted in more than 70,000 immigrants being able to use their voting rights or choice in the general election on June 23, 2013. The study of Political Science in his undergraduate education and European Politics at the master's level that it applied resulted in victory at the Socialist Party in Gjirokaster and many other districts. This is why Veliaj was appointed as Minister of Social Welfare and Youth whose finances are based on 30\% of the central government's 
annual budget. The ministry headed by Veliaj has received five important reforms for 1.5 years. Firstly, the Pensioners Reform which is based on raising donors to 93,392 people.

Secondly, Job Opportunities. This reform was carried out by connecting all local offices and businesses in one interaction model so as to facilitate recruitment and quality assurance of employment. Thirdly, payment of social welfare. The spirit of justice learned in his political lectures led him to create an electronic point-based system that evaluates 12,000 fake beneficiaries of the state budget. Fourthly, Professional Education. Political education based on people's intellectuality that he learned during college led him to adopt a German education system that combines apprenticeship with vocational education so that professional and quality human resources are available. Fifthly, the Guarantee of Justice for Persons Politically Persecuted. Veliaj initiated the process of opening State Security files. This was done by Veliaj on the basis of a call of conscience and awareness of fair political distribution for people who were detained for 25 years and blackmailed for years for certain political interests. The academic investigation effort carried out by Veliaj was approved in a law which was in the Parliament and the Authority for Disclosure of State Security Files.

\subsection{Sadiq Aman Khan}

A fundamental understanding in seeing the succession of Sadiq Aman Khan's political career as Mayor of London in 2016 can be seen from the aspect of ownership and contestation that was implemented in the campaign promises before the election was held. First, build 50,000 homes for native Londoners each year with the certainty that $50 \%$ of these homes are new houses that are affordable to rent or buy. Second, to demolish house buildings by building houses for London which involved a new team at City Hall in collaboration with policy makers and the central government. Third, mobilize more donors or investors and board members for new homes for native Londoners who seek the power of prudential loans. Fourth, it involves cooperation and incentives from the private-managed business sector so that they provide new housing investment for their workers. Fifth, build cooperation with councils, housing associations, and cooperatives to help invest their land and resources effectively, including differentiating the proper receipt of resources between purchasing and leasing. Sixth, the use of public land with a profit. Seventh, the provision of houses intended for old Londoners who are not only inhabited by one person, but can have more than one person with a management system involving the government and the private sector. The seven promises constitute political capital in participating in elections based on non-disciplinary and intolerant facts faced by Londoners. This intolerant and indisciplinary condition fostered a "sense of belonging" in Sadiq Khan to be fought for in the election and implementation of political promises. This is what causes the people of London to feel sympathy and assume that the political promises expressed by Khan are more realistic and rational that they are currently facing.

Londoners as rights owners in determining their mayors consider aspects of "ownership" and heroism. Londoners, numbering 5.74 million, produced a joint consensus that the majority of election winners fell to candidates who had a "sense of belonging" to common and shared problems they felt were related to shelter or residence. The emergence of Sadiq Aman Khan as a symbol that responds to their problems makes him a hero who considers the principle of political and social sensitivity to society in general. It is considered a contrast that behind the swift campaign related to housing or shelter there is Khan's desire to build a business and industrial city on an international level. Both of these desires are narratives of opposing opposites. The desire of industrial and business cities referred to by Khan is that City Hall is targeted to become a national (UK) and regional (EU) business city [42]. This desire is certainly based on some Londoners working in the business field so that their career rights and aspirations are accommodated in Khan's two bargaining powers, namely "ownership" and heroism during the election campaign.

The results of the election for the mayor of London were won by the Labor Party. The election takes place in two rounds. The first round produced data that Sadiq Khan from the Labor Party with 1,148,716 (44.2\%) and 909,755 from Zac Goldsmith (35\%) from the Conservative Party. The second round produced data that Khan was elected with a total of 1,310,143 votes and Goldsmith with 994,614 votes [42].

Social as an important element in the victory of Sadiq Khan in the election of the mayor of London can be seen from his involvement in symbolic organization politically and agent or self identity socially. Khan's identity can be known as someone who is not of descendants or residents of 
the original London. He is a representation of minority citizens in London. Minorities in London consist of many tribes and races of migrants who come from Pakistan, the Black Caribbean, Black Africa, or India. Khan as an agent of the Labor Party has an inner bond based on the same feelings and fate. This can be known in general that the Labor Party is not a majority or dominant party. The Labor Party has followers, sympathizers, and cadres who are immigrants or non-Londoners. Labor as a minority party becomes a symbolic organization that is automatically identical with minority citizens [40]. Khan's personal identity as a representation of an ethnic minority is also in proportion to the Sikh community as a minority community that had great sacrifice and contribution in the First World War. The succession of the Workforce leadership contest and leadership representatives who paid attention to this community with a draft of attention from 2015 to 2020 reflecting the political maturity of the British Sikhs is directly proportional to Khan's program and promises. This invited two sympathizers who chose Sikhism among a minority of immigrants; and indigenous minorities with native or British identity [40].

\subsection{Hadia Tajik}

The success of Hadia Tajik in occupying a political position as Minister of Culture is inseparable from the structural features that are available to her. This particularity is a nature that must be accepted. Unique and special features in discussing Hadia Tajik political careers including gender and minority groups. This is based on the participation of women and minorities involved in politics. Data shows that 67 women in parliament with 169 seats (almost 40\%), seven women among 19 Supreme Court Justices, 3 women from seven political party leaders represented in parliament, and 10 women from 20 ministers in government as a form of negative stereotypes that are not in line in the spirit of democracy [43]. Tajik Hadia is a minority figure based on religious values affiliation in the form of followers of Islam [44]. This was one of the reasons the prime minister appointed Hadia Tajik as Minister of Culture in September 2012. The figure of Tajik as the minority representative who became the first minister was a response and tangible evidence in long-standing International Law. International law states that since 1970 the voting rights of non-citizens have been legalized in many political agendas in many European countries; in particular at the local election level for EU and national non-EU [45]. Hadia Tajik is a minority figure who comes from Pakistan and he is one of three minority figures who managed to sit in parliamentary seats [45].

Considerations taken into account in seeing the capacity of Hadia Tajik as minister of culture (2012) can be seen in the parliamentary elections (2009) which involved aspects of networking, the surge in struggles, and heroism offered in the form of videos circulated via YouTube. The use of digital storytelling for party political purposes is a relatively new method and phenomenon. Identification of the political aspects present in the five videos identifies the internet as a form of effort to apply international-based social networks; video content that communicates selfrecording and vision as a form of passion or excitement in indirectly based social struggles; and persuasive efforts so that politicians can communicate media messages through video publications on the web because political advertising is prohibited on television as a form of translating aspects of heroism [44]. This is why Tajik is known as a "political celebrity" promoted by the Labor Party and professional multimedia company (CIK Media). This also makes the scientific discipline of Technology, Information and Communication (ICT) experience a development that gave birth to a new type of internet application (Web 2.0 iv). Her innovation and creative power became the talk of the Norwegian people so that his political selling power was increasing.

The relation between symbolic organization and contestation becomes a significant consideration in impressing the Tajik Hadia as a negative figure. This impression came from outside figures or opposing figures stating that Tajik is an online victim performed by the Labor Party as a symbolic organization which is involved in contestation and competition to win sympathizers and or voters in the 2009 parliamentary elections [44]. Negative ordering of Tajik precisely made her get empathy from prospective voters (Legislative Election, 2009) [46] and even made himself an idol for the younger generation for the next few years (2012) which was then used as material for his consideration to be appointed as Minister of Culture.

Self-actualization by Hadia Tajik during his youth can be traced from his self-motivation towards the scientific discipline he chose. He took the B.A. in journalism at Stavanger University College. He continued his studies at the master's level with a concentration in Human Rights Studies at Kingston University, England from 2004 to successfully obtain a Masters degree in 2005. This 
motivation was developed based on his desire to be involved in efforts to manage human civilization. This is why she decided to return to study at the Masters level by choosing the concentration of law studies at the University of Oslo and successfully received a Master of Law in 2012.

The political career pursued by Tajik is directly proportional to the Human Rights program she learned while studying at Kingston University. Efforts to ensure the equitable distribution and acceptance of justice are done by engaging in political activities from an early age. This is what causes the stretch of social relations they have is dominated by circle of friends who have political interests and talents. One of the proofs of political activity that Tajik has worked on is his involvement as the leader of the Youth League from 1999 to 2002. It was this political career that made him develop and was entrusted to become vice chairman of the Rogaland AUF in 2003. Her expertise in social empowerment was pursued by Tajik in his career in the organizations he had participated in made his vertical political communication relations expand even more until she was appointed as an adviser to the Minister of Labor and Social Inclusion, Bjarne Håkon Hanssen. Her appointment as an advisor to the ministry was related to the study of Law he had studied in the Master of Law at the University of Law. The role of this legal study experience was applied by Tajik in giving direction to the Minister of Labor and Social Inclusion related to the problem of poverty alleviation and unemployment efficiently without sacrificing the legal basis and laws in force in Norway. Academic ability in the field of law has evolved along with the experiences that come and went, such as her appointment as an adviser to Prime Minister Jens Stoltenberg in 2008. Academic abilities in the field of Human Rights that Tajik has studied have also developed along with his career experiences in government. This is evidenced by his appointment as political adviser to the Minister of Justice Knut Storberget in 2008 to 2009.

\section{Conclusion}

This research shows that the diversity of minority attributes in a person becomes the main capital in winning political contestation directly through elections; or indirectly through a one-sided appointment. This is indicated by the five Muslim politicians who are able to sit in political office with the capital of political biography, social biography, and / or intellectual biography. Another thing that can be concluded is that every Muslim politician in Europe who succeeded in achieving certain political achievements or positions is not always based on a personal modality consisting of political biography, social biography, and intellectual biography all at once. Five European Muslim politicians studied and researched by the writer have only one or two of the three modalities that should be fulfilled to become a Muslim politician in Europe..

\section{References}

[1] N. Breznau, J. Kelley, and V. Lykes, "A Clash of Civilizations? Preferences for Religious Political Leaders in 86 Nations," J. Sci. Study Relig., vol. 50, no. 4, pp. 671-691, 2014.

[2] M. Evans and J. Kelley, Australian economy and society2002: Religion, morality, and public policy in international perspective, 1984-2002. Sidney: Federation Press, 2004.

[3] M. Hout and C. S. Fischer, "Why more Americans have no religious preference: Politics and generations," Am. Sociol. Rev., vol. 6, no. 72, pp. 165-90, 2012.

[4] L. Lugo, The World's Muslim: Religion, Politics, and Society. Washington DC: The Pew Forum on Religion \& Public Life, 2013.

[5] U. Jandevi, "New media for increasing political participation in Indonesia," Int. J. Commun. Soc., vol. 1, no. 1, pp. 1-8, 2019.

[6] L. Lugo, The World's Muslim: Religion, Politics, and Society. Washington DC: The Pew Forum on Religion \& Public Life, 2013.

[7] D. Miller, Principles of Social Justice. Washington DC: Harvard University Press, 1999.

[8] M. Ulfah and A. Barry, "Indonesia Leader Forum, post-truth and political interests in social media and television,” Int. J. Commun. Soc., vol. 1, no. 1, pp. 17-25, 2019. 
[9] F. F. Lotan, "Making a positive internet through Socmed Agawe Guyub," Int. J. Commun. Soc., vol. 1, no. 1, pp. 9-16, 2019.

[10] K. Jaya, "Venezuela's communication dynamics in rejection of humanitarian assistance from United States of America," Int. J. Commun. Soc., vol. 1, no. 1, pp. 26-33, 2019.

[11] Z. Salvatore, Dogmatism and Theory of Interdependence between Libertarian and Equalitarian Process : A Study in Reciprocal Evaluation. Arizona: The University of Arizona, 1959.

[12] T. DiPrete, Horizontal and Vertical Mobility in Organizations. New York: Cornell University, 1987.

[13] T. Anjum, "Civil Society in Muslim Contexts: The Problématique and a Critique of Euro-American Perspectives," Islam. Stud., vol. 51, no. 1, 2012.

[14] A. C. D'Appollonia, "Researching the Civil Rights and Liberties of Western Muslims," Rev. Middle East Stud., vol. 46, no. 2, pp. 200-215, 2012.

[15] L. Diamond, "Rethinking Civil Society: Towards Democratic Consolidation," J. Democr., vol. 5, no. 6, pp. 4-18, 1994.

[16] D. Murray and J. P. Verwey, Victims of Intimidation: Freedom of Speech within Europe's Muslim Communities. Trowbridge: Wiltshire :The Cromwell Press dan The Centre for Social Cohesion, 2008.

[17] D. Hanlon, "Making Micronesia: A Political Biography of Tosiwo Nakayama," Am. Hist. Rev., vol. 120, no. 4, pp. 1471-1472, 2014.

[18] A. Astapova, "Political Biography: Incoherence, Contestation, and Elements of the Hero Pattern in the Belarusian Case,” J. Folk. Res., vol. 53, no. 2, pp. 31-62, 2016.

[19] D. Fadillah, "Pola Komunikasi Internal Brajamusti Menjelang Pilkada Kotamadya Yogyakarta 2017," Informasi, vol. 47, no. 1, 2017.

[20] D. Fadillah, L. Zhenglin, and D. Hao, "Social Media and General Elections in Malaysia 2018 and Indonesia 2019,” J. Komun. ISKI, vol. 4, no. 1, pp. 1-8, 2019.

[21] S. Tomanović, "Agency in the social biographies of young people in Belgrade," J. Youth Stud., vol. 15 , no. 5, pp. 605-620, 2012.

[22] U. Beck and E. Beck-Gernsheim, Individualization. London: Sage Publication, 2002.

[23] J. Brannen and A. Nilsen, "Young people's time perspectives: from youth to adulthood," Sociology, vol. 36, no. 3, pp. 513-539, 2002.

[24] K. Evans, "Taking control of their lives? Agency in young adult transitions in England and the New Germany," J. Youth Stud., vol. 5, no. 3, pp. 245-270, 2002.

[25] D. Fadillah, "Strategi komunikasi pembentukan budaya organisasi," Humanika, vol. 14, no. 1, 2014.

[26] B. Stauber, A. Pohl, and A. Walther, "Youth: actor of social change," Tubingen, 2009.

[27] S. Tomanovic, Growing up in Belgrade. Shaping of young people's social biographies in families from the two social strata. Belgrade: Institute for Sociological Research, 2010.

[28] T. H. Eriksen, Fredrik Barth: An Intellectual Biography. London: Pluto Press, 2015.

[29] D. O. Martínez, "Intellectual Biography, Empirical Sociology and Normative Political Theory: An Interview with Tariq Modood," J. Intercult. Stud., vol. 34, no. 6, pp. 729-741, 2013.

[30] T. Modood, Not Easy Being British: Colour, Culture, and Citizenship. London: Trentham Books, 1992.

[31] T. Modood, Multicultural Politics: Racism, Ethnicity, and Muslims in Britain. Minneapolis: University of Minnesota Press, 2005.

[32] T. Modood, Still Not Easy Being British: Struggles for a Multicultural Citizenship. London: Trentham Books, 2010.

[33] P. Gruner, "Jilani Chowdhury becomes Islington's new Mayor, 20 years after arriving from Bangladesh,” Islington Tribune. 
[34] T. Hastings and D. MacKinnon, "Re-embedding agency at the workplace scale: Workers and labour control in Glasgow call centres," Environ. Plan. A Econ. Sp., vol. 4, no. 1, pp. 104-120, 2017.

[35] S. Hennekem and D. Bennett, "Creative Industries Work across Multiple Contexts: Common Themes and Challenges," Pers. Rev., vol. 46, no. 1, pp. 68-85, 2017.

[36] M. D. Syamsuddin, "The Muhammadiyah Da'wah and Allocative Politics in the New Order Indonesia," Stud. Islam. Indones. J. Islam. Stud., vol. 2, no. 2, p. 40, 1995.

[37] J. O'Sullivan, "The Real British Disease," Quadrant, vol. 50, no. 1, p. 14, 2006.

[38] M. Ulfah, C. Fajri, and D. Fadillah, "Pemahaman Literasi media Di Lingkungan Pengurus Pimpinan Wilayah Aisyiyah daerah Istimewa Yogyakarta Periode 2015-2020," Informasi, vol. 47, no. 2, 2017.

[39] L. Smith, "How to Use Social Media to Build Brand Trust," Convince \& Convert, LLC Global HQ, 2019. [Online]. Available: https://www.convinceandconvert.com/social-media-strategy/use-socialmedia-to-build-trust/.

[40] N. Martin, Do Ethnic Minority Candidates Mobilise Ethnic Minority Voters? Mostly Not. London: democraticaudit, 2016.

[41] "Challenges and Perspectives of Citizenship Education in Central and South Eastern Europe," in Networking European Citizenship Education, Zegreb, 2009.

[42] The Electoral Commission, Media Handbook: Mayor of London and London Assembly Elections. London: Electoral Commission Press Office, 2016.

[43] United States Department of State, "Country Reports on Human Rights," 2019.

[44] E. Bakoy, "The Hadia Story: Digital Storytelling in Election Campaigns," Int. J. Media, Technol. Lifelong Learn., vol. 16, no. 2, pp. 248-267, 2010.

[45] M. Morad, "Political Participation of Immigrants through Voting and Representation:The Case of Norway,” R\&D Res. Discuss., vol. 7, no. 3, pp. 3-29, 2004.

[46] B. Bimber and R. Davis, No Title. Oxford: University Press, 2003. 